<症例報告 $>$

前治療歴のない胆管細胞由来肝原発肉腫の一切除例

\begin{tabular}{|c|c|c|c|c|c|c|c|}
\hline 明子 ${ }^{1) 2)}$ & 平岡 & 淳 ${ }^{1) *}$ & 浅木 & 彰則 ${ }^{3)}$ & 中西 & 公王 ${ }^{4)}$ & 植木秀太朗 ${ }^{1)}$ \\
\hline 美帆 ${ }^{1)}$ & 相引 & 利彦1) & 奥平 & 知成 ${ }^{1)}$ & 宮本 & 勇次 ${ }^{1)}$ & 富田 英臣 ${ }^{1)}$ \\
\hline 加 $^{1)}$ & 須賀 & 義文 ${ }^{1)}$ & 祵 & 信明 ${ }^{1)}$ & 宮 & 英樹1) & 栄治1) \\
\hline$之^{1)}$ & 了崎 & 秀樹5) & D & 智治6) & & 郎 ${ }^{1)}$ & \\
\hline
\end{tabular}

要旨：症例は 41 歳女性, 右上腹部痛と微熱を主訴に近医受診, 造影 $\mathrm{CT}$ で肝膿瘍が疑われ当院 へ紹介された. 超音波検査で B-mode で肝 S8 ドーム下に辺縁不整で内部不均一な $50 \mathrm{~mm}$ 大の充 実性腫瘤として描出され，造影超音波検査で多血性悪性腫瘍を疑った. Dynamic CTでは, 動脈 相で周囲が淡く造影され内部は hypovascular な横隔膜浸潤を伴った腫瘍として描出された. FDG$\mathrm{PET} / \mathrm{CT}$ では腫瘍部に FDG の集積（SUV max 13.7）と，右心横隔膜角，右内胸，右鎖骨上リ ンパ節にも FDG 集積がみられ, 肉腫など悪性腫瘍を疑った。 入院 6 日目に開腹手術を施行, 開 腹時に肝被膜下出血所見もみられた. 切除標本の病理組織では腫瘍組織は紡錘形細胞, 多辺形細 胞が増殖し肉腫様組織であった. CAM5.2 (+), Vimentin $(+), \operatorname{CK} 7(+), \operatorname{CK} 19(-), \mathrm{He}-$ patocyte $(-)$ で胆管細胞由来の肉腫と診断した。胆管細胞癌はそれ自体比較的予後不良な癌腫 であるが, その肉腫様変化は極めて稀でさらに予後不良である. 被膜外進展, 腫瘍出血を来した 胆管細胞由来の肝原発肉腫の一例を経験したので報告する.

索引用語：胆管細胞癌肉腫様肝内胆管癌造影超音波

\section{はじめに}

胆管細胞癌はそれ自体比較的予後不良な癌腫である が, その肉腫様変化は極めて稀でさらに予後不良であ る。今回, 我々は被膜外進展, 肝被膜下出血を来した 胆管細胞由来の肝原発肉腫の一例を経験したので報告 する。

\section{症例}

症例 : 41 歳, 女性.

主訴：右上腹部・背部痛, 微熱.

既往歴：特記事項なし。輸血歴なし.肝疾患の既往 なし.

1）愛媛県立中央病院消化器病センター内科

2）済生会今治病院内科

3）四国がんセンター消化器内科

4）市立大洲病院内科

5）愛媛県立中央病院消化器病センター外科

6）愛媛県立中央病院病理診断部

*Corresponding author: hirage@m.ehime-u.ac.jp ＜受付日2015年12月19日 > <採択日2016年3月5日 >
家族歴：特記なし.

職業歴：学校教諭. 印刷業等への従事歴なし.

生活歴：常習飲酒歴なし. 喫煙歴なし。

薬剤曝露歴：なし。

現病歴：2014 年 9 月下旬に 38 度台の発熱あり,その 後も 37 度台の微熱が持続していた. また, 同時期より 体動時の右側胸部から背部の鈍痛を自覚していた. 2014 年 10 月某日, 仕事中に急激に疼痛が増強したため近医 受診. 血液検査所見上，炎症反応高值であった．造影 CT 検查にて肝臓右葉ドーム下に肝膿瘍を疑われて, 同 日当科紹介入院となる.

入院時現症 : 身長 $152.5 \mathrm{~cm}$, 体重 $41.8 \mathrm{~kg}$, 体温 $37.5^{\circ} \mathrm{C}$, 血圧 110/86 mmHg, 脈拍 90 回/分. 眼瞼結膜に軽度貧 血を認め, 眼球結膜に黄疸はなし. 腹部は平坦で軟, 右側腹部に比較的強い圧痛を認める。肝脾は触知しな い. 下腿浮腫なし。

入院時血液検查成績（Table 1）：軽度の貧血, 軽度 の低蛋白血症がみられた. 白血球数の増多はないが, CRP は著明に高值を呈した. 血沈反応も 60 分值で軽度 増加がみられた。肝炎ウイルスマーカーはB 型, C 
Table 1 Laboratory data on admission

\begin{tabular}{lc|lc|lc}
\hline WBC & $7350 / \mu l$ & $\mathrm{AST}$ & $18 \mathrm{U} / l$ & $\mathrm{CRP}$ & $14.58 \mathrm{mg} / \mathrm{d} l$ \\
Neut & $68.2 \%$ & $\mathrm{ALT}$ & $14 \mathrm{U} / l$ & $\mathrm{Fe}$ & $45 \mu \mathrm{g} / \mathrm{d} l$ \\
Lym & $25.0 \%$ & $\mathrm{ALP}$ & $382 \mathrm{U} / l$ & $\mathrm{FER}$ & $278 \mathrm{ng} / \mathrm{m} l$ \\
Eos & $0.5 \%$ & $\mathrm{~T}-\mathrm{bil}$ & $0.4 \mathrm{mg} / \mathrm{d} l$ & $\mathrm{Cu}$ & $294 \mu \mathrm{g} / \mathrm{d} l$ \\
Baso & $0.3 \%$ & $\mathrm{LDH}$ & $254 \mathrm{U} / l$ & $\mathrm{Ceruloplasmin}$ & $42 \mathrm{mg} / \mathrm{d} l$ \\
Mono & $6.0 \%$ & $\gamma \mathrm{GTP}$ & $57 \mathrm{U} / l$ & $\mathrm{Glu}$ & $73 \mathrm{mg} / \mathrm{d} l$ \\
$\mathrm{RBC}$ & $385 \times 10^{4} / \mu l$ & $\mathrm{ChE}$ & $237 \mathrm{U} / l$ & $\mathrm{HbA} 1 \mathrm{c}$ & $5.9 \%$ \\
$\mathrm{Hb}$ & $10.9 \mathrm{~g} / \mathrm{d} l$ & $\mathrm{ZTT}$ & $8.3 \mathrm{U}$ & $\mathrm{AFP}$ & $2.9 \mathrm{ng} / \mathrm{m} l$ \\
$\mathrm{Ht}$ & $33.7 \mathrm{Fl}$ & $\mathrm{TTT}$ & $0.9 \mathrm{U}$ & $\mathrm{AFP}-\mathrm{L} 3$ & $<0.5 \%$ \\
Plt & $34.2 \times 10^{4} / \mu l$ & $\mathrm{TP}$ & $6.6 \mathrm{~g} / \mathrm{d} l$ & $\mathrm{PIVKA}-\mathrm{II}$ & $10 \mathrm{mAU} / \mathrm{m} l$ \\
ESR $(60 / 120 \mathrm{~min})$ & $66 / 71 \mathrm{~mm}$ & $\mathrm{Alb}$ & $2.9 \mathrm{~g} / \mathrm{d} l$ & $\mathrm{CEA}$ & $0.9 \mathrm{ng} / \mathrm{m} l$ \\
PT & $64.0 \%$ & $\mathrm{BUN}$ & $7.6 \mathrm{mg} / \mathrm{d} l$ & $\mathrm{CA} 19-9$ & $7.0 \mathrm{U} / \mathrm{m} l$ \\
APTT & $38.4 \mathrm{sec}$ & $\mathrm{Cr}$ & $0.53 \mathrm{mg} / \mathrm{d} l$ & $\mathrm{sIL}-2 \mathrm{receptor}$ & $669 \mathrm{U} / \mathrm{m} l$ \\
Fibrinorgen & $672.0 \mathrm{mg} / \mathrm{d} l$ & $\mathrm{UA}$ & $3.4 \mathrm{mg} / \mathrm{d} l$ & $\mathrm{HBsAg}$ & $(-)$ \\
FDP & $7.4 \mu \mathrm{g} / \mathrm{m} l$ & $\mathrm{Na}$ & $139 \mathrm{mEq} / l$ & $\mathrm{HBcAb}$ & $(-)$ \\
D $\cdot$ D dimer & $4.0 \mu \mathrm{g} / \mathrm{m} l$ & $\mathrm{~K}$ & $4.2 \mathrm{mEq} / l$ & Anti-HCV & $(-)$ \\
AT-III & $109.9 \%$ & $\mathrm{Cl}$ & $101 \mathrm{mEq} / l$ & $\mathrm{ANA}$ & 40 \\
& & $\mathrm{Ca}$ & $8.5 \mathrm{mg} / \mathrm{d} l$ & AMA $(\mathrm{M} 2)$ & 1.9 \\
\end{tabular}

型ともに院性, 耐糖能異常はなく,CA19-9, AFP, PIVKAII なと腫瘍マーカーの増加はみられなかった。

腹部超音波検査所見 (Fig. 1)：B mode にて肝右葉ドー ム下に肝内から肝外へ突出する辺縁不整で, 境界明瞭, 内部不均一な低エコー性の $50 \mathrm{~mm}$ 大の充実性腫瘤が描 出された (Fig. 1a). 腫瘍内部に明らかな液状変性の所 見はなく，またカラードプラでは内部に腫瘍血管と考 えられる血流シグナルが検出された (Fig. 1b). ペルフ ルブタン（ソナゾイド ${ }^{\circledR} 0.5 \mathrm{ml} /$ body）を用いた造影超 音波検査 (Fig. 1c) では, arterial phase で比較的小さ い血管が病変内部へ流入して周囲肝と同程度までほぼ 全体が濃染を呈した。一部に内部壊死を類推させる造 影効果を伴わない部位もみられた. portal phase で wash outがみられ, post vascular phase では全体が境界明瞭 な八頭状の defect を呈した (Fig. 1d).

腹部 CT 所見 (Fig. 2)：肝 S8 から肝外に突出する不 整形の腫瘤性病変. 肝被膜を破り肝周囲に進展がみら れ, 横隔膜へも浸潤し肺底部に突出していた。動脈相 で腫瘤の造影効果は軽度で, 内部は平衡相にかけてわ ずかに造影された，腫瘍周囲の濃染域は血流異常と思 われた，腫瘤は胆囊からは離れており，また胆道系と の明らかな関連を示唆する所見は画像上指摘できなかっ た. 横隔膜上に 2 カ所リンパ節腫大があり，転移が疑 われた。
腹部 MRI 所見：S8 の腫瘤は T1WI で低信号, T2WI で不均一な軽度高信号を呈する. DWI では辺縁主体に 高信号であり，ADC 值は低下していた。

FDG-PET/CT 所見(Fig. 3)：S8 の腫瘤に高度の FDG 集積（SUV $\max =13.7 ）$ がみられた. 右心横隔膜角, 右内胸, 右鎖骨上リンパ節に結節上の FDG 集積立進 $(\mathrm{SUV} \max =4.2)$ を伴い, リンパ節転移が疑われた.

入院後経過：トラマドール，アセトアミノフェン， NSAIDs 内服にて疼痛コントロールを行った. 各種画像 検査より肝被膜外・横隔膜浸潤・多発リンパ節転移を 伴った肝原発肉腫などの稀な悪性度の高い肝腫瘍を疑 い, 症状緩和を目的として入院 6 日目に開腹手術を行っ た。

術中所見：S8 ドーム下から腫瘍が肝外に突出し, 横 隔膜と広範囲に癒着がみられた，右横隔膜下に血性腹 水があり腫瘍からの出血が疑われた。周囲には血腫や 腫瘍片が固着していた．胸腔内から触診すると一部腫 瘍が胸腔内に突出するが, 肺との癒着は認めなかった. 術中エコー検査では明らかな脈管侵襲はみられず, S8 区域切除, 横隔膜部分切除, 横隔膜上リンパ節摘出を 行った.

切除標本肉眼像（Fig. 4）: 白色調で, 周囲との境界 は明瞭. 腫瘍は $5 \times 4 \mathrm{~cm}$, mass forming type の発育形 態を呈していた。また背景肝は正常肝であった（切除 

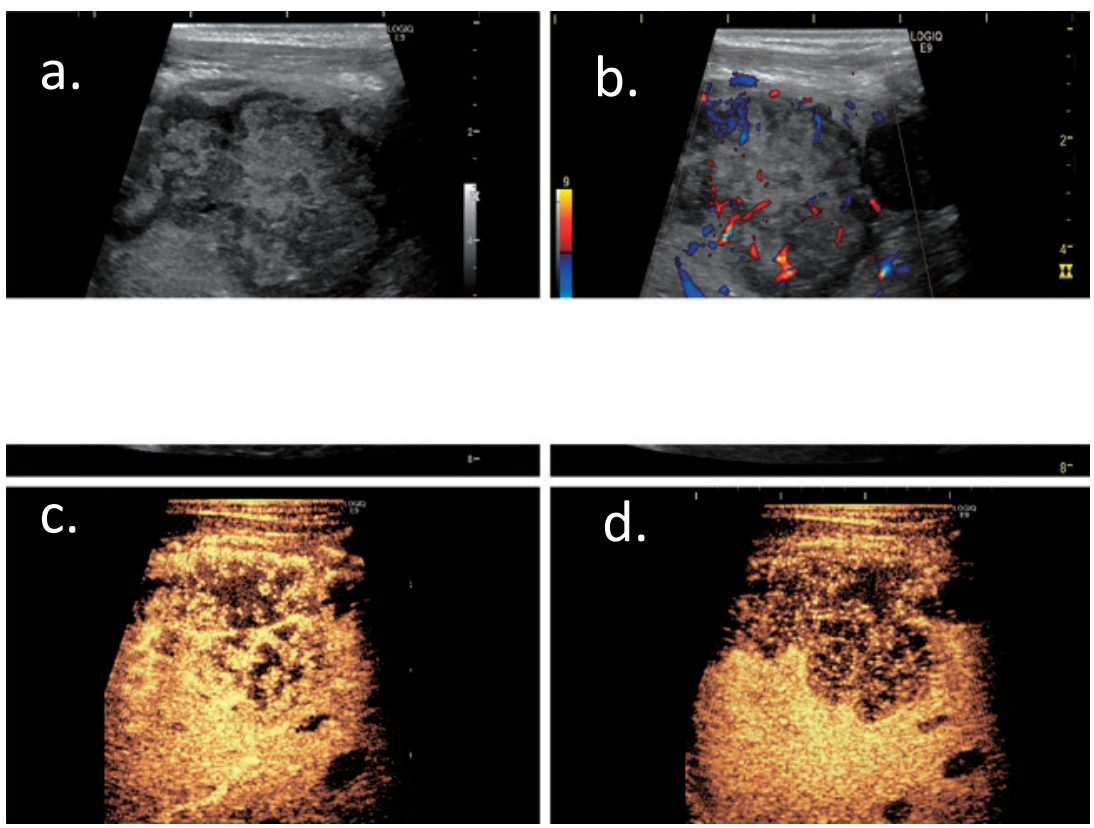

Fig. 1 Abdominal ultrasonography.

Conventional B-mode ultrasonography (US) showed hypo- and heterogeneous solid tumor in $8^{\text {th }}$ segment of the liver (a). Tumor vessel flow signal detected by ColorDoppler US (b). Contrast enhanced US with Sonazoid ${ }^{\circledR}(0.5 \mathrm{ml} /$ body) showed strong enhancement of the tumor in the early vascular phase (c), while a wash out pattern was seen in the portal phase (d). In the post-vascular phase, the tumor was clearly revealed as a defect.

総肝重量 184 g, Eg, Fc-, Fc-inf+, Sf-, S3, Vp0, Vv0, $\mathrm{Va} 0, \mathrm{~B} 0, \mathrm{P}+, \mathrm{N}+, \mathrm{SM}+, \mathrm{NL}(\mathrm{F} 0))$ T4N1M0 Stage IVB.

病理組織学的所見 (Fig. 5)：HE染色(Fig. 5a)では, 紡錘形細胞, 多辺形細胞が交錯して増殖し肉腫と診断 した。壊死，炎症細胞浸潤も中程度にみられる。明ら かな管腔形成はみられなかった．免疫染色で CAM5.2 $(+)$, Vimentin $(+)$, CK7 $(+)$, CK19 $(-)$, Hepatocyte $(-)$, Desmin $(-), \operatorname{SMA}(-)$ であった (Fig. $5 b)$. 以上より胆管細胞癌特殊型の肉腫様癌と診断した. 胆囊, 胆道系への浸潤などは切除標本の組織上も確認 されなかった.

術後経過：術後 9 日目に退院となった. 2014 年 11 月から 2015 年 2 月まで術後化学療法として GEM+CDDP を行った. 化学療法開始 2 力月後の CT では SD であっ たが, 2015 年 2 月の PET-CT で, 胸部のリンパ節腫大 はサイズ変化が見られなかったものの，右横隔膜や肝 周囲, 胃周囲に播種結節が出現し, $\mathrm{PD}$ の判断で $\mathrm{S} 1$
内服加療にレジメン変更となった. 2 月から 5 月は SD の範囲で経過したが, その後は播種結節が緩徐に増大 し, 腹痛も徐々に増悪した. 相談のうえ, 7 月以降, 術 後 16 力月現在まで, 外来通院で緩和治療を継続してい る.

\section{考察}

胆管細胞癌は山中らの報告1)では原発性肝癌における 約 5\% と報告され, 更に胆管細胞癌に肉腫様変化を伴う

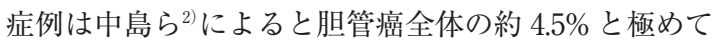
稀とされる．医学中央雑誌で「肝内胆管癌」「胆管細胞 癌」肉腫」癌肉腫」を key word として検索すると, 2000 年から 2014 年までで 19 例の報告がみられだ) 21) (Table 2). 過去の報告例および自験例, 計 20 例の臨床像は, 男性が 12 例 $(60.0 \%)$, 年齢平均 65.0 歳 (41 歳から 80 歳), 平均腫瘍径は $9.3 \mathrm{~cm}$. 診断時に自覚症状を訴えて いたものは 13 例 $(65.0 \%)$ あり, 発熱や右上腹部痛が 多かった. Nakajima らの報告2)では腫瘍マーカーの陽 


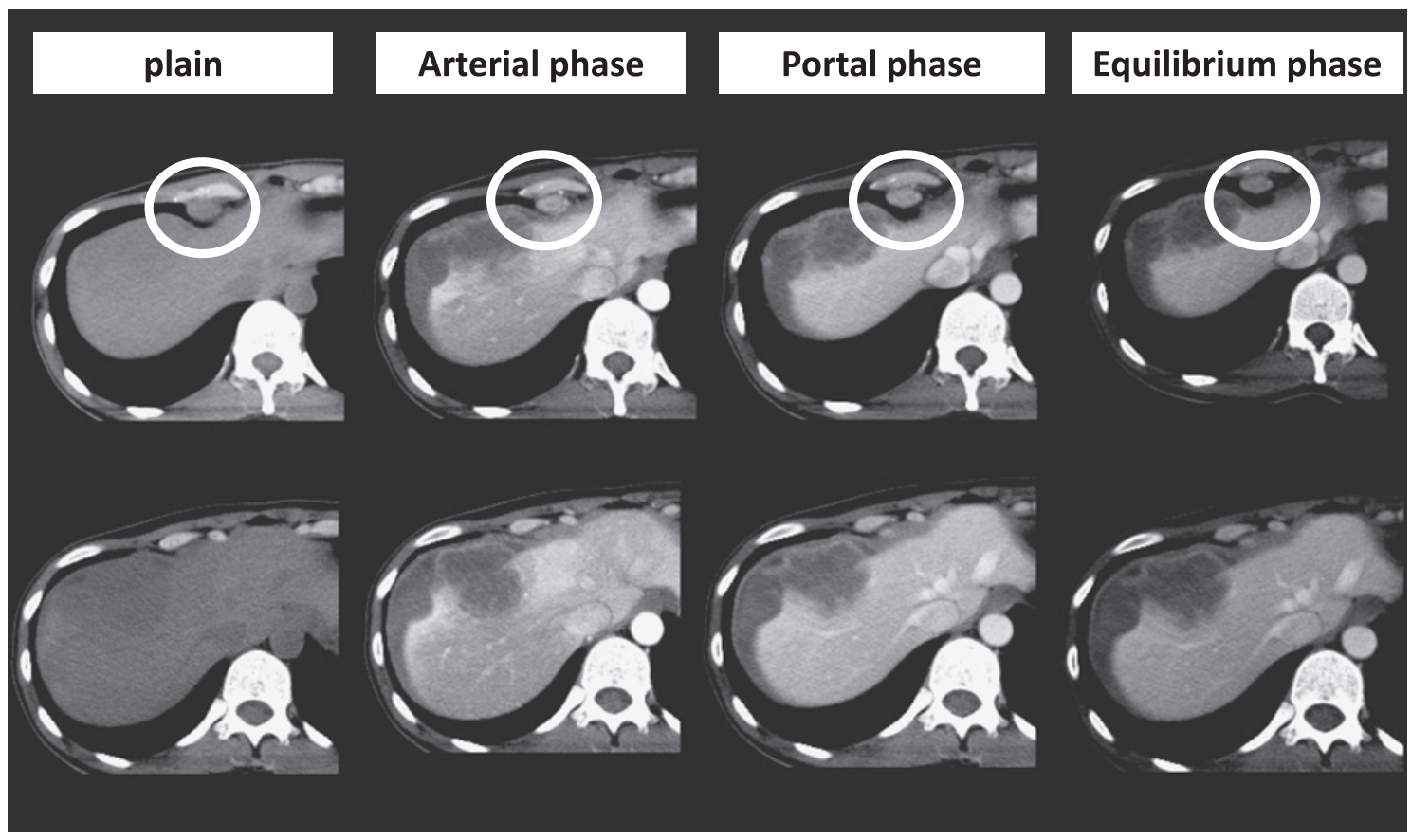

Fig. 2 Dynamic computed tomography (CT). The tumor was revealed as a low density area in plain CT findings. The tumor periphery was slightly enhanced in the arterial and portal, and equilibrium phase. Lymph node swelling was detected (circle) and lymph node metastasis was suspected.

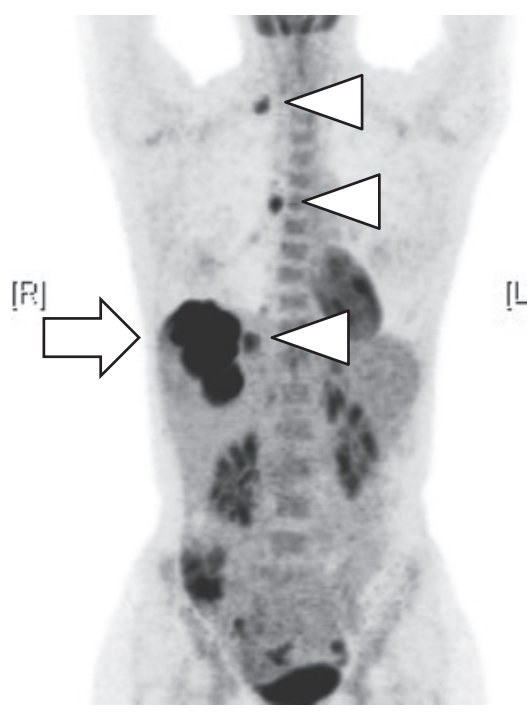

Fig. 3 FDG-positron emission/computed tomography findings. A high level of FDG uptake was observed in the tumor (SUV $\max =13.7$ ) (arrow). Swollen lymph nodes also showed uptake of FDG (SUV max $=4.2$ ) (arrowhead).
性率は著しく低いとされ，われわれの検討でも CEA は 2 例 (10\%)，CA19-9 は 7 例 (35\%) でのみ増加がみ られていた．本症例も発熱と右上腹部痛の主訴を契機 に発見されたが，腫瘍マーカーはいずれも正常範囲内 で術前の血液検査データから診断につながる手がかり はなかった，過去の報告例では，発熱や CRP の増加が 目立つことが挙げられているが, これらは非特異的な 所見であり，本例のように肝膿瘍を含む感染症が疑わ れた例も存在する ${ }^{3)}$. 本症例では増加していた CRP は術後に低下しており，感染ではなく腫瘍による影響 があったと考えられた。

本疾患では, 典型的な画像所見は確立されていない. 造影 CT では辺縁が徐々に造影されることが多いとさ $れ^{5) 111}$, 術前画像診断を胆管細胞癌としたものは 7 例 (35.0\%), 他に混合型肝癌, 肝囊胞腺癌, 悪性リンパ腫, 胃腫瘍，肝膿瘍など診断は多岐にわたっていた．生検 を施行されたものは 4 例（超音波ガイド下肝腫瘍生検 3 例, 内視鏡的逆行性胆管造影手技による胆管生検 1 例) で, 1 例は中分化型肝細胞癌, 残り 3 例は肉腫様癌 の診断であった，本疾患では，典型的な画像所見が存 


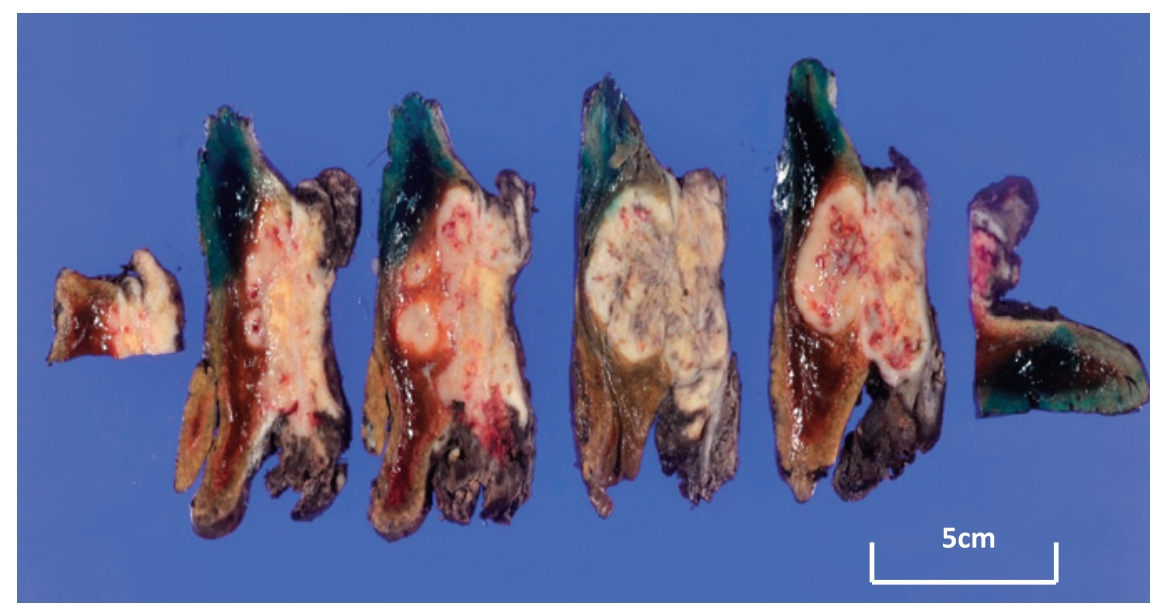

Fig. 4 Macroscopic findings of specimen. The gross tumor type was single nodular with extra-nodular growth $[5 \times 4 \mathrm{~cm}, \mathrm{Eg}, \mathrm{Fc}-, \mathrm{Fc}-\mathrm{inf}+$, Sf-, S3, Vp0, Vv0, Va0, B0, P+ , $\mathrm{N}+, \mathrm{SM}+, \mathrm{NL}(\mathrm{F} 0)]$.

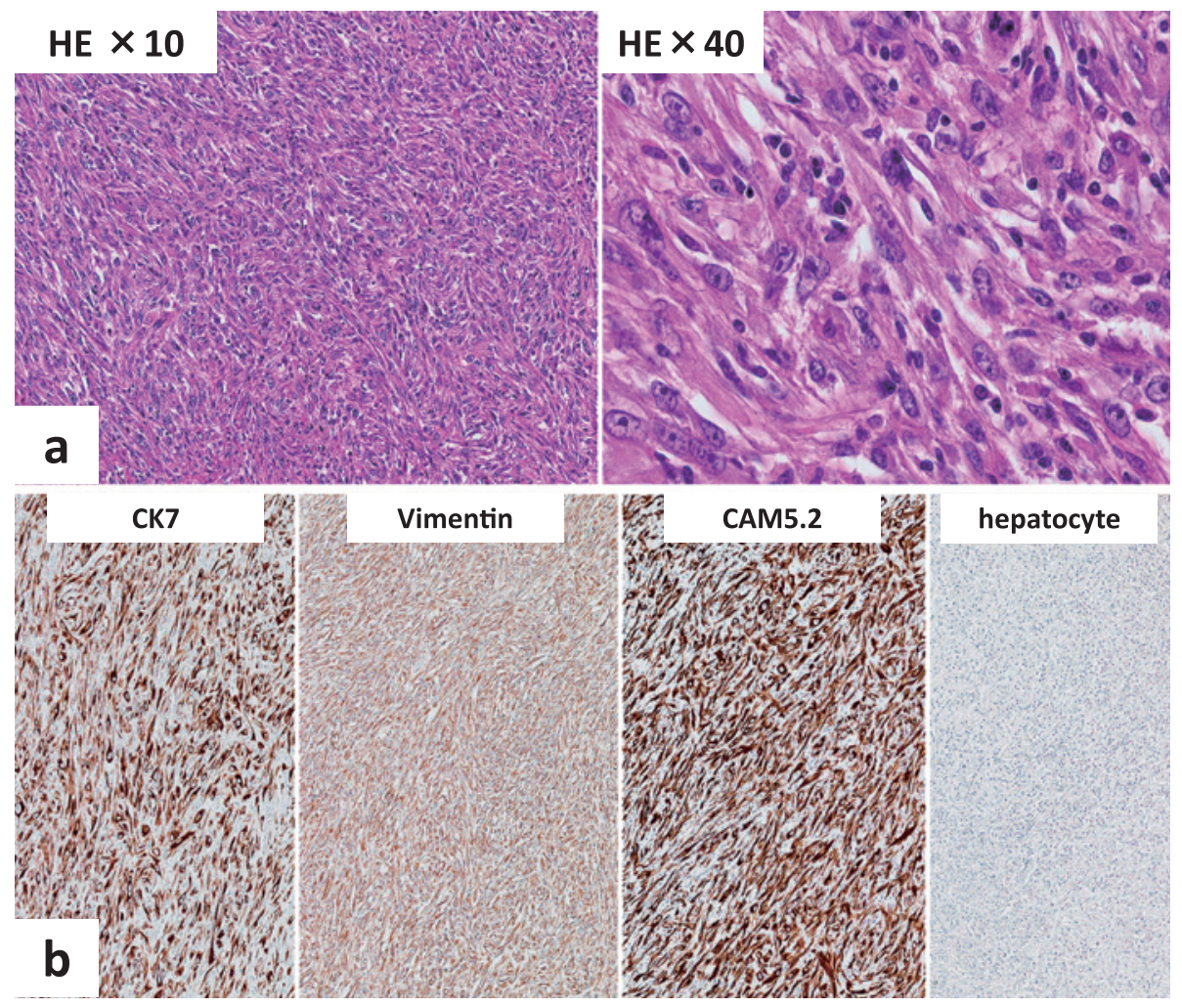

Fig. 5 Histological findings. a. H\&E staining revealed proliferation of spindle cells. There were no ductal structures. b. In immune staining, the tumor was positive for CK7 (+), vimentin, and CAM5.2, and negative for CK19, hepatocytes, desmin, and SMA. 
Table 2 Previously published reports of cholangiocellular sarcoma.

\begin{tabular}{|c|c|c|c|c|c|c|c|c|c|c|c|c|}
\hline No. & author & $\begin{array}{c}\text { Reference } \\
\text { no. }\end{array}$ & Year & Age & Sex & $\begin{array}{l}\text { Chief } \\
\text { complaint }\end{array}$ & $\begin{array}{l}\text { Tumor } \\
\text { size } \\
(\mathrm{cm})\end{array}$ & Metastasis & $\begin{array}{l}\text { Hep- } \\
\text { atitis }\end{array}$ & AFP & PIVKA-II & CEA \\
\hline 1 & Shibata & 3) & 2001 & 41 & male & $\begin{array}{l}\text { fever, rt. abd. } \\
\text { Pain }\end{array}$ & 4 & NA & $\mathrm{HBV}$ & 3.3 & NA & 1.6 \\
\hline 2 & Matsuoka & 4) & 2002 & 58 & male & none & 3 & NA & $\mathrm{HBV}$ & 2.4 & 18 & 1.83 \\
\hline 3 & Kaibori & 5) & 2003 & 69 & female & $\begin{array}{l}\text { fever, abd. } \\
\text { pain }\end{array}$ & 20 & NA & NA & normal & NA & normal \\
\hline 4 & Kawahara & 6) & 2004 & 56 & male & fatigue & 6 & NA & $\mathrm{HBV}$ & 9.3 & 22 & 2.2 \\
\hline 5 & Tokumaru & 7) & 2005 & 61 & male & fever & 14 & NA & NA & 3.4 & 23 & 1.5 \\
\hline 6 & Hashimoto & 8) & 2006 & 66 & male & none & 5 & NA & NA & 5.3 & 20 & 4.4 \\
\hline 7 & Endo & 9) & 2008 & 67 & male & icterus & NA & PVT & NA & normal & normal & 276 \\
\hline 8 & Yasuda & 10) & 2010 & 80 & female & $\begin{array}{l}\text { epigastralgia, } \\
\text { fever }\end{array}$ & 8 & NA & NA & NA & NA & 2.7 \\
\hline 9 & Sasaki & 11) & 2010 & 62 & male & none & 4.5 & PVT & $\mathrm{HBV}$ & 172.8 & 864 & NA \\
\hline 10 & Matsui & 12) & 2010 & 66 & female & abd. pain & 9 & NA & NA & 3.5 & 18 & $<0.4$ \\
\hline 11 & Kato & 13) & 2011 & 71 & male & epigastralgia & 9 & $\begin{array}{c}\text { direct } \\
\text { kidney } \\
\text { invasion }\end{array}$ & $\mathrm{HCV}$ & 3 & 22 & 2.9 \\
\hline 12 & Nakajima & 14) & 2012 & 77 & female & rt. back pain & 16 & NA & NA & normal & normal & normal \\
\hline 13 & Tsukahara & 15) & 2012 & 70 & male & epigastralgia & 6 & NA & NA & normal & normal & normal \\
\hline 14 & Yamamoto & 16) & 2012 & 80 & female & none & 3.5 & NA & NA & normal & normal & normal \\
\hline 15 & Shimomura & 17) & 2013 & 64 & male & $\begin{array}{l}\text { rt. abd. Pain, } \\
\text { fatigue }\end{array}$ & 13 & rupture & NA & 2 & NA & 19.3 \\
\hline 16 & Jindou & 18) & 2013 & 61 & female & none & 3.3 & seeding & $\mathrm{HBV}$ & 2.5 & 6 & 2.5 \\
\hline 17 & Edagawa & 19) & 2013 & 59 & female & abd. pain & 10 & NA & NA & 6.1 & NA & 3.1 \\
\hline 18 & Kiuchi & 20) & 2014 & 75 & male & none & NA & NA & NA & NA & NA & 2.2 \\
\hline 19 & Shoji & 21) & 2014 & 75 & male & none & 24 & $\begin{array}{c}\text { direct } \\
\text { diaphragm } \\
\text { invasion }\end{array}$ & $\mathrm{HBV}$ & 1.9 & 10 & 3.6 \\
\hline 20 & $\begin{array}{l}\text { Present } \\
\text { case }\end{array}$ & & & 42 & female & rt. abd. pain & 5 & $\begin{array}{l}\text { LN, direct } \\
\text { diaphragm } \\
\text { invasion }\end{array}$ & NA & 2.9 & 10 & 0.9 \\
\hline
\end{tabular}

HBV: hepatitis B virus, HCV: hepatitis C virus, NA: not available, PVT: portal vein thrombosis, LN: lymph node, HCC: heatocellular BSC: best supportive care

在せず，内部壊死や腫瘍の囊腫様変化，壊死部感染や 胆管閉塞から囊胞内感染を来すなど臨床像も多彩であ り, さらに前述のように血液検査も非特異的であるこ とから, 術前の診断が困難であることが多い.

ペルフルブタン (ソナゾイド®)を用いた造影超音波 検查を行った，造影超音波の報告はほとんどなく，検 索した範囲では 1 例のみ ${ }^{12}$ であった. 松居らの報告 ${ }^{12}$ に よると血管相で病変周囲が濃染し, 内部は周囲管と同
程度の染影を呈し, 蛇行の少ない既存の血管と思われ る血管の走行がみられ，後血管相では通常の肝内胆管 癌と同様に明暸な八つ頭状の defect を呈し, 明らかな 皮膜形成の所見はなかった。自験例でも小血管の流入 や後血管相の所見等がみられ, 松居らの報告と類似し ていた.

FDG-PET/CT は悪性度評価・遠隔転移診断において 非常に有用である. 東ら ${ }^{22}$ は, 肝内胆管癌の報告で, 中〜 


\begin{tabular}{|c|c|c|c|c|c|c|c|c|c|c|c|}
\hline CA19-9 & $\begin{array}{l}\text { Pre-treatment } \\
\text { diagnosis }\end{array}$ & $\begin{array}{l}\text { Treat- } \\
\text { ment }\end{array}$ & CK7 & CK19 & Vimentin & SMA & $\begin{array}{l}\text { Recur- } \\
\text { rence }\end{array}$ & $\begin{array}{l}\text { Months } \\
\text { until } \\
\text { recurrence }\end{array}$ & $\begin{array}{l}\text { Treatment } \\
\text { for } \\
\text { recurrence }\end{array}$ & $\begin{array}{c}\text { Alive/ } \\
\text { dead }\end{array}$ & $\begin{array}{l}\text { Observa- } \\
\text { tion period } \\
(\mathrm{mo})\end{array}$ \\
\hline 19 & abcess & OPE & + & NA & NA & NA & - & & & alive & 1 \\
\hline 52 & $\mathrm{HCC} / \mathrm{CCC}$ & OPE & + & + & + & NA & + & 2 & $\mathrm{BSC}$ & dead & 3 \\
\hline 3665 & $\begin{array}{c}\text { gastric cancer } \\
\text { (leiomyosar- } \\
\text { coma) }\end{array}$ & OPE & $\mathrm{NA} *$ & NA * & + & NA & + & NA & NA & dead & 3 \\
\hline 16 & $\begin{array}{l}\mathrm{HCC} / \mathrm{CCC} / \\
\text { metastasis/ } \\
\text { sarcoma }\end{array}$ & OPE & + & + & - & NA & NA & NA & NA & NA & NA \\
\hline 8 & $\begin{array}{l}\text { malignant } \\
\text { lymphoma }\end{array}$ & OPE & + & NA & NA & NA & + & 4 & CRT & dead & 9 \\
\hline 28 & $\mathrm{CCC}$ & OPE & NA & NA & + & NA & + & 10 & BSC & dead & 16 \\
\hline 426 & $\mathrm{NA}$ & OPE & NA & NA & + & NA & - & & & alive & 16 \\
\hline 9876 & $\begin{array}{c}\text { cystadenocarci- } \\
\text { noma }\end{array}$ & OPE & NA & NA & + & - & + & 2 & BSC & dead & 3 \\
\hline NA & $\mathrm{HCC}$ & OPE & - & NA & + & + & + & 3 & BSC & dead & 4 \\
\hline 5.7 & $\mathrm{CCC}$ & OPE & + & + & + & NA & - & & & alive & 20 \\
\hline 15.9 & $\mathrm{CCC}$ & $\mathrm{OPE}$ & NA & NA & + & NA & + & 2 & S-1 & dead & 6 \\
\hline 1620 & $\begin{array}{l}\text { cystadenocarci- } \\
\text { noma/CCC }\end{array}$ & $\begin{array}{c}\mathrm{OPE}+ \\
\mathrm{GEM}\end{array}$ & NA & NA & NA & NA & + & 2 & $\mathrm{BSC}$ & dead & 4 \\
\hline 301 & $\begin{array}{c}\mathrm{CCC} / \text { combined } \\
\mathrm{HCC}\end{array}$ & $\begin{array}{c}\mathrm{OPE}+ \\
\text { GEM }\end{array}$ & - & NA & + & NA & + & 8 & GEM & alive & 27 \\
\hline normal & $\mathrm{CCC}$ & OPE & + & + & - & - & - & & & alive & 84 \\
\hline 3170 & $\mathrm{CCC}$ & OPE & + & + & $\mathrm{NA}$ & NA & + & 0.5 & $\mathrm{BSC}$ & dead & 0.6 \\
\hline$<2$ & $\mathrm{HCC}$ & OPE & + & + & + & NA & + & 2 & $\mathrm{CDDP}$ & dead & 8 \\
\hline 3.2 & NA & $\begin{array}{c}\mathrm{OPE}+ \\
\mathrm{GEM}\end{array}$ & + & - & - & NA & - & & & alive & 12 \\
\hline 6 & $\mathrm{CCC}$ & OPE & NA & NA & + & + & - & & & alive & 12 \\
\hline 14 & $\mathrm{CCC}$ & OPE & NA & + & $\mathrm{NA}$ & NA & + & 12 & OPE & alive & 29 \\
\hline 7.0 & $\begin{array}{l}\text { sarcomatous } \\
\text { HCC }\end{array}$ & $\begin{array}{l}\mathrm{OPE}+ \\
\text { GEM/ } \\
\text { CDDP }\end{array}$ & + & - & + & - & & & & alive & 16 \\
\hline
\end{tabular}

carcinoma, CCC: cholangiocellular carcinoma, OPE: surgical resection, GEM: gemcitabine, CDDP: cisplatin, CRT: chemoradiotherapy,

高分化型では FDG 集積が低く, 低分化型では高いと報 告している.一方, 瀬尾ら ${ }^{23}$ は FDGの集積において SUV $\max =8.50$ をカットオフ值として二群に分けて無再発生 存について比較すると, 8.50 以上を呈した群で有意に無 再発生存率が低いと報告している. また枝川ら ${ }^{19)}$ の報告 でも FDG-PET は悪性度を予測するうえで有用であった とされている. 本例も病変部に高度の FDG 集積 (SUV $\max =13.7)$ がみられており, 非常に悪性度の高い腫瘍
であることが予想された，また，前述のように術前診 断が困難であるため, 低分化な胆管細胞癌として手術 加療が行われた症例の中に，本例のような肉腫様に変 質したものが含まれていることも予想される.

本症例は胆管細胞癌の成分は見られず腫瘍組織全体 が肉腫様の組織であった。切除標本における免疫染色 では, CK7 陽性, hepatocyte 陰性であり, 胆管細胞由 来の癌肉腫と診断した。これまでの報告では胆管細胞 
癌の組織と肉腫様組織が混在し, 移行像がみられたと のものがほとんどである，癌腫から肉腫様変化を呈す る機序としては, 高橋ら ${ }^{24}$ は癌細胞が多分化能を有する 未熟な細胞へ一旦分化して, その後肉腫へと再分化す ると考察している. 本例は病変全体が肉腫様組織へ置 換されていたことから，これまでの報告例の中でも極 めて悪性度が高い例であると考えられる。他, ウイル ス性慢性肝炎を背景とした肝細胞癌に対する内科的局 所療法後に, 腫瘍細胞の変性・壊死・再生を介し, 肉 腫様変化に関与するとする説もある。本例は背景とな る肝疾患は有していないが, 肝炎ウイルス陽性例は 7 例（HBV6 例, HCV1 例）と全体の $35 \%$ にみられてお り, 肝細胞癌との合併・鑑別が問題となる例も散見さ れている ${ }^{1118)}$.

肉腫様変化を伴う胆管細胞癌の予後は極めて不良で ある。早期に血行性, リンパ行性転移，腹膜播種を来 して急速な転機をたどることが多く，生存期間は平均 4 力月と報告されている77. 本疾患は, 手術が唯一の根 治性の高い治療である. 今回の検討症例のなかでは最 長で術後 7 年間生存例 ${ }^{16}$ があり, 根治的に切除が可能で あれば予後の改善が見込める可能性がある。また海外 の報告例では術後補助化学療法を施行しながら 29 力月 生存中という報告 ${ }^{25)}$ もる. しかし, 術後早期に再発を 来す症例がほとんどであり, 根治的手術症例 13 例にお いても 7 例 $(53.8 \%)$ に術後平均 4.7 力月後に再発がみ られていた，術後補助化学療法として, 通常の胆管細 胞癌に準じたレジメン (S-1 + CDDP, S-1 + GEM, GEM $+\mathrm{CDDP}$ など）が用いられているが，現時点では補助 化学療法においても, 再発に対する有効な化学療法は 確立されておらず，十分な成績ではない，本例はリン パ節転移を有する進行例であったため, 術後は GEM $+\mathrm{CDDP}$ で外来化学療法を開始した，その後 TS-1 単独 内服に切り替えたが, 病状の進展に伴い 16 力月経った 現在は外来にて緩和治療を継続している，本症例は診 断当初からリンパ節転移を有しており，開腹手術は治 癒切除を目指したものではなかったが, 肝の主病変の 減量切除と初期化学療法によって一定期間進行阻止が 得られ, 幸運にも肝内病変の再発がみられずに肝予備 能も 1 年以上も維持できている. 減量手術は, 術後 16 カ月現在も生存が得られていることに寄与していると 考えられる.

今後さらなる症例の蓄積により, 有効な診断法・化 学療法・治療法の確立が待たれる.

\section{文献}

1) 山中若樹, 山崎 普, 幕内雅敏, 他. 肝内胆管癌取 扱い規約 (第 4 班) と今後の課題一外科からの論点. 肝胆膵 $2000 ； 41 ： 495-501$

2) Nakajima T, Tajima Y, Sugano I, et al. Intrahepatic cholangiocarcinoma with sarcomatous change. Cancer 1993; 72: 1872-1877

3) 柴田直哉, 上田裕滋, 大内田次郎, 他. 肝内胆管癌 の特殊型(1) 肉腫様変化を伴った 1 例. 消化器画像 $2001 ; 3: 617-621$

4) 松岡欣也, 平井隆二, 太田徹哉, 他. 肝切除後急速 に腹膜播種をきたした肉腫様変化を示す混合型肝癌 の 1 例. 日臨外科会誌 $2002 ; 35: 1654-1658$

5) Kaibori M, Kawaguchi Y, Yokoigawa N, et al. Intrahepatic sarcomatoid cholangiocarcinoma. J Gastroenterol 2003; 38: 1097-1101

6）川原 弘, 大塚俊美, 島中公志, 他. 肝細胞癌と胆 管細胞の 2 方向への形質分化を示した肝原発未分化 癌の 1 例. 肝臓 $2004 ; 45: 678-683$

7) 徳丸勝悟, 長谷川洋, 坂本英至, 他. 肉腫様変化を 伴った胆管細胞癌の 1 例. 日消外会誌 $2005 ; 38$ ： $521-526$

8) 橋本真治, 中郡聡夫, 小西 大, 他. 肉腫様变化を 伴った肝内胆管癌の 1 例. 日臨外会誌 $2006 ; 67$ ： $2162-2167$

9）遠藤耕介, 寺嶋宏明, 今井幸弘, 他. 胆管腫瘍栓を 伴った肝癌肉腫の 1 例. 日消外会誌 $2008 ; 41: 99$ 104

10）保田紘一郎, 仁熊健文, 高木敏行, 他. 肉腫様変化 を伴う肝内胆管癌 1 例. 肝臓 $2010 ; 51 ： 521-527$

11）佐々木滋, 高橋進一郎, 木下 平, 他. 術後急速な 再発形式をとった肉腫様形態を伴う細胆管癌の 1 例. 日消外会誌 $2010 ； 43: 1240-1245$

12）松居剛志, 辻 邦彦, 一箭珠貴, 他. 前治療歴のな い肝原発 Sarcomatoid carcinoma の 1 例. 日消誌 $2010 ; 107: 1175-1183$

13）加藤孝章, 片桐 聡, 有泉俊一, 他. 肉腫様変化を 伴った肝内胆管癌の 1 例. 日外科系連会誌 2011 ; $36: 681-686$

14）中島高広, 岡村明治. 巨大肝内胆管癌肉腫の 1 例. 日消誌 $2012 ； 109 ： 1590-1597$

15）塚原哲夫, 奈良 聡, 尾島英知, 他. 肉腫様成分か らなる左門脈腫瘍栓 $(\mathrm{Vp} 3)$ を伴った肝内胆管癌の 一例. 日本消化器外科学会誌 $2012 ; 45: 732-739$

16）山本敏雄, 宇奈手一司, 牧野正人, 他. 術後長期生 存した肝原発肉腫の 1 例. 日臨外会誌 $2012 ; 73$ ： 
(2016)

$102-107$

17）下村 治, 福永 潔, 中野順隆, 他. 肝切除後極め て急激な再発を認めた肉腫様変化を伴う G-CSF 産生肝内胆管癌の一例. 日本消化器外科学会雑誌 $2013 ; 46$ (1) : 41-49

18）神道 修, 鈴木昌八, 福本和彦, 他. 肝動脈化学塞 栓治療歴のある肉腫様変化を伴った肝内胆管癌の 1 例. 肝臓 $2013 ; 54: 589$-599

19）枝川 真, 萱島寛人, 吉住朋晴, 他. FDG-PET で高集積を示した肉腫様变化を伴う肝内胆管癌の 1 例. 日臨外会誌 $2013 ; 74: 201-206$

20）木内亮太, 杉浦禎一, 岡村行泰, 他. 左肝管から発 生した真の癌肉腫の 1 切除例. 日本消化器外科学会 雑誌 $2014 ; 47: 34-41$

21）正司政寿, 高村博之, 林 泰寛, 他. 繰り返す局所 療法後に発生した肉腫様変化を伴う肝内胆管癌再発
の 1 例. 日臨外会誌 $2014 ； 75 （ 7 ） ： 2001-2007$

22) 東 達也, 西井龍一, 波多野悦郎, 他. 画像診断の 基本と実際 画像検査をどう使いこなすか その特 徵, 使い分け, 組み合わせ FDG-PETによる胆道 系疾患診断．消臨 $2008 ； 11: 666$-670

23) 瀨尾 智, 波多野悦郎, 北村好史, 他. 肝内胆管癌 における FDG-PET の術前検査としての有用性. 消 化器科 $2008 ; 47: 277-283$

24) 高橋芳久, 近藤福雄, 福島純一, 他. 肝臓の癌肉腫. 肝胆膵 $2011 ； 63$ (4) : 601-605

25) Malhotra S, Wood J, Mansy T, et al. Intrahepatic Sarcomatoid Cholangiocarcinoma. J Oncol 2010; 2010: 701476. doi: 10.1155/2010/701476. Epub 2010 Apr 29

本論文内容に関連する著者の利益相反：なし 


\title{
Resected intrahepatic cholangiocellular sarcoma: case report and review of literature
}

\author{
Akiko Toshimori ${ }^{122)}$, Atsushi Hiraoka ${ }^{1 / *}$, Akinori Asagi ${ }^{3)}$, Kimio Nakanishi $^{4)}$, Hidetaro Ueki ${ }^{1)}$, Miho Kaneto ${ }^{1)}$, \\ Toshihiko Aibiki ${ }^{1)}$, Tomonari Okudaira ${ }^{1)}$, Yuji Miyamoto ${ }^{1)}$, Hideomi Tomita ${ }^{1)}$, Hiroka Yamago ${ }^{1)}$, \\ Yoshifumi Suga $^{1)}$, Nobuaki Azemoto ${ }^{1)}$, Hideki Miyata ${ }^{1)}$, Eiji Tsubouchi $^{1)}$, Tomoyuki Ninomiya ${ }^{1)}$, \\ Hideki Kawasaki ${ }^{5}$, Toshiharu Maeda ${ }^{6}$, Kojiro Michitaka ${ }^{1)}$
}

\begin{abstract}
A 41-year-old Japanese woman was referred to us for further examinations of continuous right hypochondralgia, low grade fever, and a hepatic tumor in the 8 th segment $(5.0 \mathrm{~cm}$ in diameter), suspected to be an abscess. Dynamic CT showed enhancement of the periphery of the tumor, as well as invasion to the diaphragm and lymph node swelling, while contrast enhanced abdominal ultrasonography (US) revealed the entire mass to be hypervascular with a partial avascular area. The hepatic tumor and swollen lymph nodes showed a high level of FDG uptake (SUVmax=13.7) in positron emission tomography/CT findings. Hepatic resection of the tumor was performed as palliative treatment and it was diagnosed as a cholangiocellular sarcoma, which is a special type of cholangiocellular carcinoma (CAM5.2 +, vimentin + , CK7 +, CK19 - , hepatocyte -, desmin -, SMA -). Sixteen months after resection, the patient was being treated with supportive care, following progressive disease treatment with chemotherapy.
\end{abstract}

Key words: cholangiocellular carcinoma cholangiocellular sarcoma contrast enhanced ultrasonography

1) Gastroenterology Center, Ehime Prefectural Central Hospital, Ehime, Japan

2) Department of Internal Medicine, Saiseikai Imabari Hospital, Ehime, Japan

3) Department of Gastroenterology, Shikoku Cancer Center, Ehime, Japan

4) Department of Internal Medicine, Ozu Hospital, Ehime, Japan

5) Department of Surgery, Ehime Prefectural Central Hospital, Ehime, Japan

6) Department of Pathology, Ehime Prefectural Central Hospital, Ehime, Japan

${ }^{*}$ Corresponding author: hirage@m.ehime-u.ac.jp

(C) 2016 The Japan Society of Hepatology 